\title{
The Dates of the Discovery of the First Peking Man Fossil Teeth
}

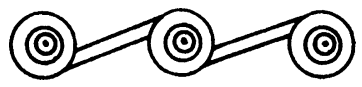

\author{
Qian Wang, Li Sun, and Jan Ove R. EbBestad
}

\begin{abstract}
Four teeth of Peking Man from Zhoukoudian, excavated by Otto Zdansky in 1921 and 1923 and currently housed in the Museum of Evolution at Uppsala University, are among the most treasured finds in palaeoanthropology, not only because of their scientific value but also for their important historical and cultural significance. It is generally acknowledged that the first fossil evidence of Peking Man was two teeth unearthed by Zdansky during his excavations at Zhoukoudian in 1921 and 1923. However, the exact dates and details of their collection and identification have been documented inconsistently in the literature. We reexamine this matter and find that, due to incompleteness and ambiguity of early documentation of the discovery of the first Peking Man teeth, the facts surrounding their collection and identification remain uncertain. Had Zdansky documented and revealed his findings on the earliest occasion, the early history of Zhoukoudian and discoveries of first Peking Man fossils would have been more precisely known and the development of the field of palaeoanthropology in early twentieth century China would have been different. KeYwords: Peking Man, Zhoukoudian, tooth, Uppsala University.
\end{abstract}

\section{INTRODUCTION}

Four fossil teeth identified as coming from Peking Man were excavated by palaeontologist Otto Zdansky in 1921 and 1923 from Zhoukoudian deposits. They have been housed in the Museum of Evolution at Uppsala University in Sweden ever since. These four teeth are among the most treasured finds in palaeoanthropology, not only because of their scientific value but also for their historical and cultural significance.

Otto Karl Josef Zdansky (born 28 November 1894 in Vienna, died 26 December 1988 in Uppsala) was the first archaeologist to excavate the Zhoukoudian site and he is credited as having discovered the first fossil teeth of Peking Man. Unlike the rest of the Zhoukoudian and Peking Man saga, however, information concerning the first teeth found during Zdansky's excavation remains obscure. Many aspects of the initial

Qian Wang is an Associate Professor of Anatomy in the Department of Biomedical Sciences at Texas A\&M University College of Dentistry in Dallas, Texas. Li Sun is an Associate Faculty of Geology in the Department of Geology and Environmental Science at Collin College in Plano, Texas. Jan Ove R. Ebbestad is the Curator of the Palaeontological Collection for the Museum of Evolution at Uppsala University in Sweden. 
discoveries are inconsistent in different accounts, especially the exact dates when the teeth were unearthed and identified (Table 1). For example, when were the first two teeth unearthed and were they identified in situ or in the lab?

Remarkable discrepancies in the information on the dates of the first Peking Man tooth fossils have previously been documented (Kundrát et al. 2015; Wang and Sun 2000; Wu and Poirier 1995; Wu and Wu 1996). However, various accounts agree that in August 1921, Johan G. Andersson, a Swedish geologist working for the National Geological Survey of China, picked up a quartz fragment from cave deposits at a small hill at Zhoukoudian while he was inspecting Zdansky's excavation there; he immediately recognized the significance of the site, which would become associated with Peking Man (Andersson 1934). Zdansky had apparently found the first Peking Man specimen, an isolated molar tooth, during that summer excavation. He uncovered a second tooth from his Zhoukoudian collections in the lab later on, yet according to Jia and Huang (1984), not release the news until 1926 during a symposium held in Beijing in connection with the visit of the Swedish Crown Prince (Black 1926; Frängsmyr 2012; Kundrát et al. 2015). Two more teeth were later discovered in his Zhoukoudian collections, making these four teeth the earliest ones collected from Zhoukoudian deposits (Frängsmyr 2012; Kundrát et al. 2015). All four teeth are currently housed in the Museum of Evolution at Uppsala University in Sweden.

In 1927, Davidson Black established a new genus and species name for Peking Man, Sinanthropus pekinensis, based on a single molar tooth fossil found by Swedish palaeontologist Birger Bohlin on 16 October 1927 (i.e., the holotype specimen in Table 1). Black (1927) was able to create this taxon based on the single tooth excavated by Bohlin in 1927 in part because Zdansky had already found two human teeth, in addition to possible stone artifacts, from the Zhoukoudian deposits (Black 1926; Zdansky 1927).

The loss of nearly all Peking Man fossils during World War II is one of the most tragic events in recent scientific history (Boaz and Ciochon 2004; Jia and Huang 1984; Shapiro 1976). Though delicate casts of original Peking Man crania, mandibles, teeth, and postcranial skeletons, along with meticulous descriptions by Black and Franz Weidenreich (the Director of the Cenozoic Research Laboratory in Beijing), provide the material basis and documentation of the morphology and variations of Peking Man, the loss of most of the original Peking Man fossils robbed the scientific field of the possibility of restudying them with new insight and technologies. Needless to say, the four teeth conserved at the Museum of Evolution at Uppsala University remain amongst its most treasured materials (Fig. 1).

Though Sinanthropus pekinensis has ceased to be used as a scientific name and all Peking Man fossils are now attributed to Homo erectus per international rules of taxonomy, the information brought to us by evidence of Peking Man and his integration into his environment has greatly enriched our understanding of the process of human evolution (Wang and Sun 2000; Wang and Tobias 2001). The evolutionary position of $H$. erectus in East Asia in relation to the evolution of modern humans remains a topic of some debate. Consequently, the development of this taxon and the events that unfolded around the Zhoukoudian site have constituted a classic chapter in the palaeoanthropology of the twentieth century (Andersson 1934; Jia 1999; Jia and Huang 1984; Wang and Sun 2000). Important discoveries and episodes there include finds of hominin fossils and artifacts, evidence of the use of fire, and later the mysterious disappearance of Peking Man fossils during World War II, followed by a search for the 
Table i. Various Accounts of the Dates of Excavation/Identification of Four Teeth of Peking Man Housed in the Museum of EVOlution, Uppsala University

\begin{tabular}{|c|c|c|c|c|c|}
\hline & FIRST TOOTH & SECOND TOOTH & THIRD TOOTH & FOURTH TOOTH & $\begin{array}{c}\text { HOLOTYPE SPECIMEN } \\
\text { TOOTH }^{a}\end{array}$ \\
\hline Catalogue no. & PMU M3550 & PMU M3549 & PMU M3887 & PMU 25719 & K11337:3 \\
\hline Tooth type & Right upper M3 & Left lower P1 & Right lower P2 & Right upper C & Left lower M1 \\
\hline Initial attribution & ?Homo sp. & ?Homo sp. & $\begin{array}{r}\text { Sinanthropus } \\
\text { pekinensis }\end{array}$ & Homo erectus & Sinanthropus pekinensis \\
\hline \multicolumn{6}{|l|}{ Source } \\
\hline Black et al. 1933 & 1923 & - & - & - & - \\
\hline Oakley et al. 1975 & 1923/1926 by Zdansky & $\begin{array}{l}1923 / 1926 \\
\text { by Zdansky }\end{array}$ & - & - & 1927 by Bohlin \\
\hline Jia and Huang 1984 & $\begin{array}{l}\text { Recognized August } \\
1921 \text { during excavation }\end{array}$ & 1926 found in lab & 1950 & - & $\begin{array}{l}\text { 10/16/1927 by Bohlin; } \\
\text { went missing } 12 / 8 / 1941\end{array}$ \\
\hline Day 1986 & 1921 by Andersson & 1923 by Zdansky & - & - & 1927 by Bohlin \\
\hline Wu and Poirier 1995 & 1921 or $1923 / 1926$ & 1921 or $1923 / 1926$ & 1921 or $1923 / 1952$ & - & - \\
\hline Wu and Wu 1996 & $1921 / 1926$ found in lab & $1921 / 1926$ found in lab & $\begin{array}{l}1923 / 1953 \\
\text { found in lab }\end{array}$ & - & - \\
\hline Wang and Sun 2000 & 1921 & 1923 & 1950 & - & 1927 \\
\hline Wood 2011 & $1923 / 1926^{\mathrm{b}}$ & - & - & - & - \\
\hline Frängsmyr 2012 & 1921 & 1921 & 1952 & 2011 & 1927 \\
\hline Kundrát et al. 2015 & 1921 & 1924-1926 & 3/19/1951-June 1952 & $\begin{array}{l}1921 \text { or } 1923 / \text { recognized by } \\
\text { Kundrát 3/21/2011 }\end{array}$ & \\
\hline
\end{tabular}

${ }^{a}$ The holotype specimen discovered by Bohlin, chronologically the third tooth found, is listed along with the fourth tooth to complete the dental array of then new genus and species, Sinanthropus pekinensis.

1923 (Entry: Zhoukoudian Locality 1 Hominins)/1926 (Entry: Zdansky). 


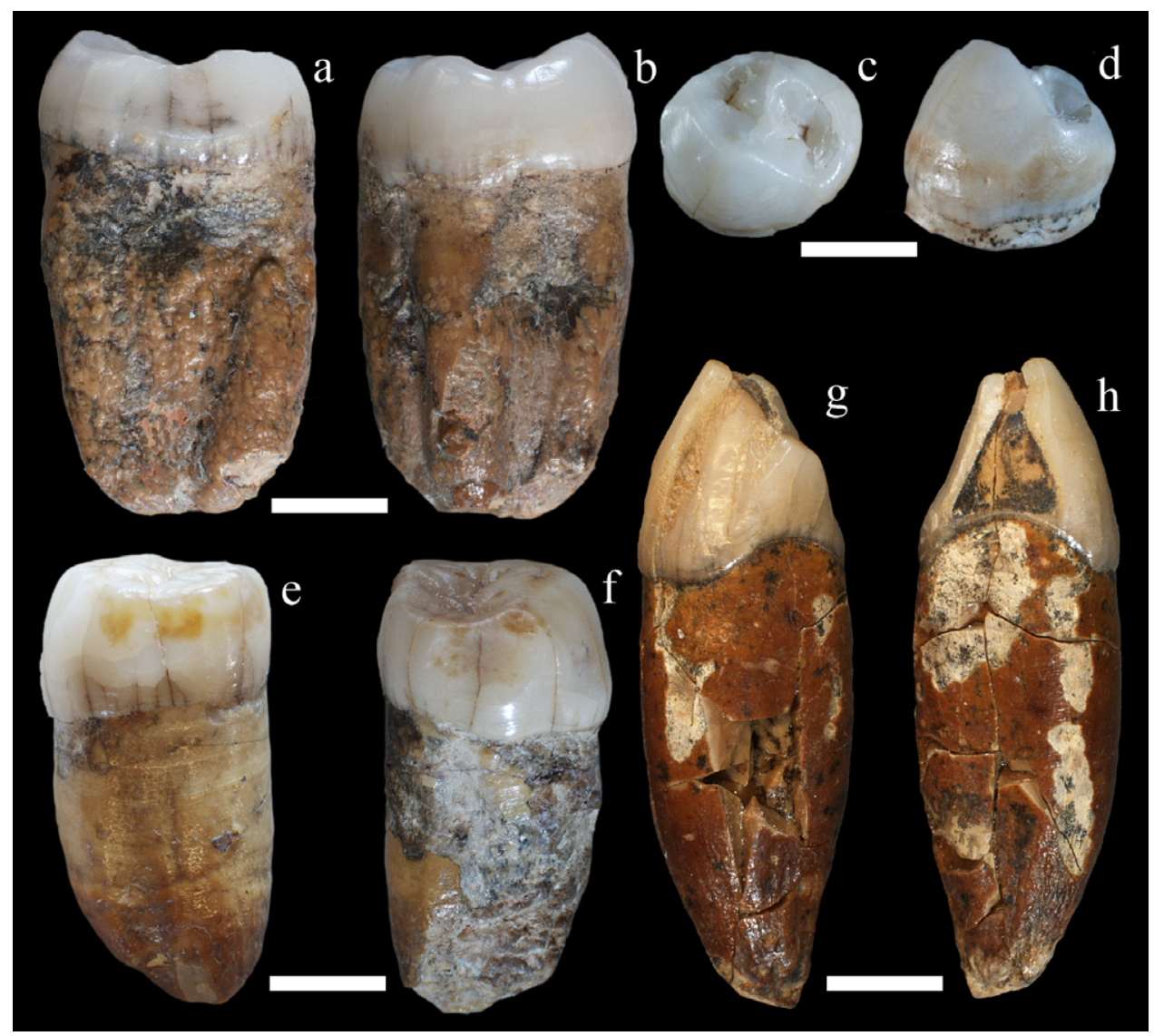

Fig. 1. The four Peking Man fossils teeth housed at the University of Uppsala in the order they were discovered. (a and b) PMU M3550, right upper M3. (c and d) PMU M3549, left lower P1. (e and f) PMU M3887, right lower P2. (g and h) PMU 25719, right upper C. Scale bar is $5 \mathrm{~mm}$.

missing fossils. The site saw many important activities conducted by such influential personalities as Johan G. Andersson, Otto Zdansky, Birger Bohlin, Davidson Black, Franz Weidenreich, Pierre Teilhard de Chardin, Wen Chung Pei, Lanpo Jia, and Wen Hao Wen. Consequentially, the story of Peking Man has fascinated scholars and laypeople alike, and has been retold many times (Boaz and Ciochon 2004; Frängsmyr 2012; Howells 1993; Jia 1999; Jia and Huang 1984; Johansson 2012; Kundrát et al. 2015; Reader 2011; Sarmiento et al. 2007; Schmalzer 2008; Shapiro 1976; Tobias et al. 2001; Van Oosterzee 2001; Wang and Sun 2000). Such previous accounts have overlooked the details of how the first human finds at the site came to light, however. In order to document the early history of the discoveries of Peking Man as precisely as possible, we examine documents derived from Zdansky's work, including his unpublished memoirs, and review the discrepancies and different interpretations in the literature concerning the historic record of early Zhoukoudian dental discoveries. 


\section{MATERIALS AND METHODS}

Extensive documents related to the teeth uncovered during Zdansky's 1921 and 1923 excavations were examined, including scientific journal publications, media reports, and interviews, in addition to Zdansky's firsthand descriptions of his discoveries in his unpublished autobiography and correspondence with Andersson, and specimen catalogues at the Museum of Evolution, Uppsala University. We particularly focused on records or accounts related to the discoveries of the first three teeth excavated and identified by Zdansky. We then discussed possible connections between these accounts to personal ambitions and scientific entrepreneurship.

\section{Results}

First tooth (PMU M3550, Right Upper M3) - It was widely believed that Zdansky found an anthropoid tooth in situ in the 1921 summer excavation, which he later attributed to Homo. Firsthand accounts from Zdansky lack precise information, however. In a preface to Otto Zdansky's (1997) unpublished autobiography, his son Göran Zdansky states that all his father's notes and diaries were stolen while he was travelling home on the transsiberian railroad in December 1923. All information from him is ambiguous and later accounts are derived either from unspecified texts or secondary sources. Nevertheless, our primary sources of information on this first tooth find are Zdansky's publications $(1927,1928,1952)$, an interview with him (Thor 1984), his unpublished autobiography (1997), and letters preserved in the archives in University of Uppsala.

Zdansky (1928) stated that he found the first molar (PMU M3550) in situ and that he discovered the premolar (PMU M3549) later when he was cleaning the material in Uppsala:

As far as I can remember, the molar was uncovered from Layer 5 or Layer 6 of Profile A (of Zhoukoudian deposits) (Zdansky 1923:86). As for the premolar, I have no such memory. I discovered it only when cleaning the material in Uppsala. Even if it had been taken from the sediment by myself, most probably it was not recognized by me because of the adhering moist clay. (translated here from Zdansky 1928:141) ${ }^{1}$

It is clear that Zdansky never made an exact statement about when he saw and recognized the first two Peking Man tooth fossils. His account only gives the following information:

1. The first tooth, a molar, was from Layer 5 or 6 . Based on the way the second tooth was introduced, he might have seen the first tooth at Zhoukoudian at the time it was first uncovered, though he did not immediately recognize it as a human tooth. The stratigraphic information is meaningful, however, as it could be used for stratigraphic correlation and geological dating.

2. The second tooth, a premolar, was uncovered from deposit samples while he was preparing specimens in Uppsala. He did not specify when he recognized the specimen. He did not specify from which layer this specimen was unearthed.

3. Zdansky did not specify whether he found the first tooth in 1921 or 1923; he did not specify if the second tooth was from deposits he dug out in 1921 or in 1923.

Andersson, the person most closely involved in the discovery of the Peking Man fossils other than Zdansky, did not give a specific date either. In a newspaper report, 
Andersson (1929) only states that two teeth were found by Zdansky in his lab in 1926. Andersson did not supply a specific year or date in his memoir, Children of the Yellow Earth: Studies in Prehistoric China (Swedish version 1932, English version 1934), indicating he did not know when and how the first tooth was found. Likewise, there is no record in the first scientific report of these two teeth by Davidson Black (1926) in the journal Nature.

Instead, the first scientific document that specifies a discovery date of "1923" for the first Peking Man tooth fossil was published in 1933, only seven years after the discovery was made known to the world by Zdansky, by a group of co-authors including Black, de Chardin, Pei, and Chung Chien Young. They specified the year of discovery as "1923", but why they did so is a mystery (Black et al. 1933). By this time, Andersson had published his memoir in Swedish and Zdansky was a faculty member in Egypt, yet there is no documentation of their having conferred with either man before this assertion.

In a 1984 interview, Zdansky clearly said that he found the first tooth during the initial excavation and that he recognized it as a hominid tooth the time (Thor 1984:96). He then stated that he kept quiet so that he would be left alone to describe the findings. It is important to remember that he did not receive any salary for the work he did in China, but Carl Wiman in Uppsala had promised that he would be allowed to work up and publish the findings (Frängsmyr 2006, 2012). However, in his autobiography many years later, he wrote that he could not recall when he found the teeth (Zdansky 1997).

Had the initial label of the first tooth been preserved at the museum, it might have helped us narrow the date of its identification. However, the earliest known "original label" reads "Sinanthropus pekinensis," indicating that the label was attached to the specimen no earlier than the year 1927, when Black established this species name (Fig. 2). Black wrote, "The species ... may be named Sinanthropus pekinensis (Black and Zdansky)" to include Zdansky as a co-designator (Black 1927:21). Though he generously listed Zdansky as the co-founder of the Sinanthropus pekinensis species name, Zdansky (1952) refrained from claiming that credit. If he had labeled the specimen, he would likely have identified the tooth as Anthropoid or ?Homo sp., which is how he assigned the teeth in his early report. However, he probably never labeled the teeth, since there are no labels by Zdansky attached to the other Zhoukoudian finds in the collection at the museum in
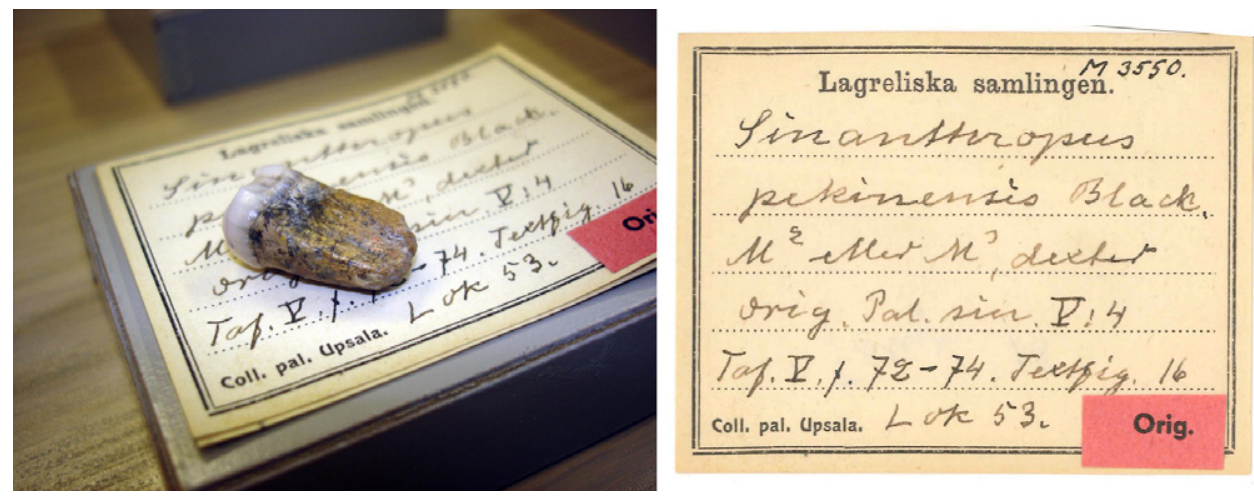

Fig. 2. The first Peking Man tooth, PMU M3550 (left) and original label (right), assigning the tooth to a new genus and species: Sinanthropus pekinensis Black. 


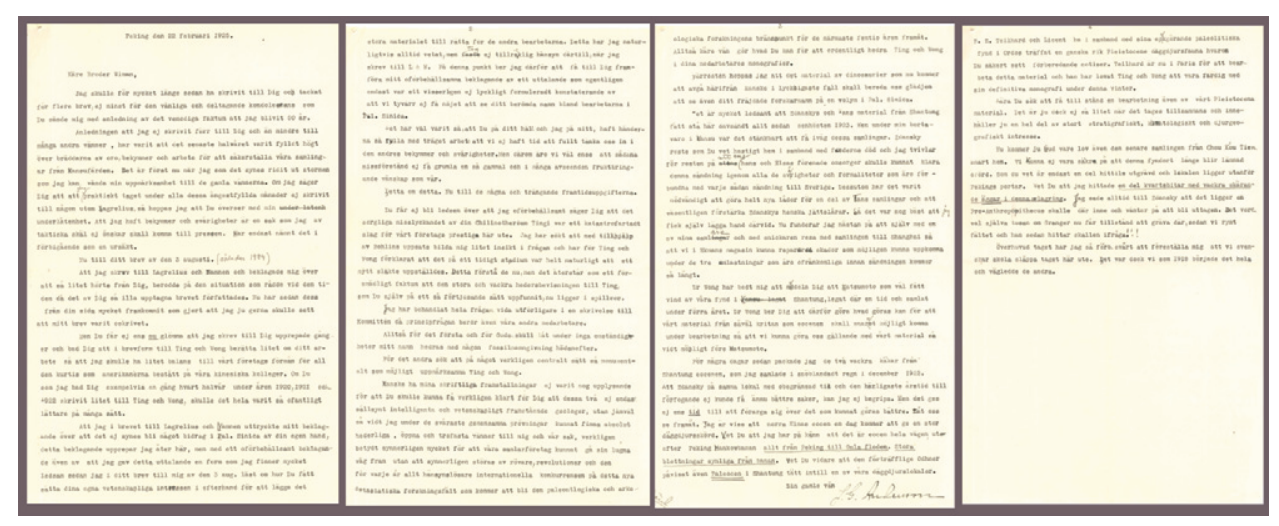

Fig. 3. Letter from Andersson to Wiman dated 22 February 1925 (Source: Museum of Evolution, Sino-Swedish collaboration letter archive, published with permission) 
Uppsala. Indeed, it has been claimed that Zdansky simply kept the two teeth in a small glass jar in a bookshelf in his workroom (Frängsmyr 2012).

Given these discrepancies, scholars have suggested that the first tooth was found either in 1921 (Jia and Huang 1984; Kundrát et al. 2015; Thor 1984; Wang and Sun 2000), 1923 (Black et al. 1933; Wood 2011:Entry Zhoukoudian Locality 1 Hominins), or 1926 (Wood 2011:Entry Zdansky). Others state that both the first and second teeth were unearthed in either 1921 or 1923, but not identified until 1926 (Wu and Poirier 1995; Wu and Wu 1996).

Second Tooth (PMU M3549, Left Lower P1) - It is generally accepted that Zdansky found the second tooth in the lab after completing his excavations. After Zdansky returned to Uppsala in January 1924, he started working on the material he had collected at Zhoukoudian in 1921 and 1923. Discoveries of the first and second teeth were announced in 1926.

Wiman (1929:3) stated that the last shipment of samples from China arrived in Uppsala on June 28, 1925. In a letter to Professor Wiman dated 22 February 1925, Andersson seems to have referred to the shipment that would arrive in Uppsala in June when he wrote, "Now, thank God, finally even the last collection from Chou K' ou Tien [Zhoukoudian] will soon be home" (translated here from Swedish; letter archived at Museum of Evolution, Uppsala University) (Fig. 3). According to this letter, the material from the 1923 excavation could not have been available to Zdansky before the summer of 1925 . While it remains unclear whether the second tooth was dug up during the 1921 or the 1923 excavations, it must have been discovered in the lab sometime between January 1924 (when Zdansky returned to Uppsala) and 1926 (when he first announced the find) (Kundrát et al. 2015).

Andersson mentioned Zdansky on page 3 of the letter and again in the postscript on page 4 , from whence the above line was quoted. The postscript continued:

We cannot be sure that this locality will be left untouched for long. As you know only a part is so far excavated and the locality is just outside the gates of Beijing. Do you know that I found some quartz pieces with beautiful cutting edges at this site. I always said to Zdansky that there is a Pro-Anthropopithecus skull in there, waiting to be excavated. Damned if Granger now gets permission to dig there, now that we have left the field and that he then finds the skull in question!!! On the whole, I find it damn hard to imagine that we Swedes should let go out here. It was after all we that in 1918 started it all and guided the others.

These comments and the date of the letter demonstrate that the finding of Peking Man fossils were unknown to Andersson at the time and that he was reluctant to leave the promising Zhoukoudian site behind. Thus, in 1925, only Zdansky would have known about the teeth (which were probably sitting in a glass jar), and he may not have fully recognized them at the time.

To reiterate, Zdansky did not specify when he uncovered the second tooth from surrounding deposits nor when he identified its human origin. He did not specify from which layer this specimen was unearthed. He also did not specify whether the second tooth was from deposits he dug out in 1921 or in 1923. This tooth was not mentioned by Black and colleagues (1933), but other scholars have argued that the second tooth was unearthed in 1921 or 1923 and then (along with the first tooth) identified in 1926 (Wu and Poirier 1995; Wu and Wu 1996), or identified between 1924 and 1926 (Kundrát et al. 2015), or only identified in the lab in 1926 (Jia and Huang 1984). Wang 
and Sun's (2000) contention that it was discovered in 1923 fits within the time bracket, but lacks confidence.

Third Tooth (PMU M3887, Right Lower P2) - The third tooth was reported by Zdansky in 1952. Wu and Poirier (1995:37-38) recorded its find date as 1921 or 1923/ 1952 (i.e., recognized in 1952 in the laboratory in Uppsala, Sweden, among the fossils excavated in 1921 and 1923). Wu and Wu (1996:91) wrote that the third tooth was "unearthed in 1923, found in lab in 1953." However, Jia and Huang (1984) stated that it was found in 1950 in the lab from Zdansky's material. They wrote that Professor Martinsson, a professor of palaeontology at Uppsala University, visited the Institute of Vertebrate Paleontology and Paleoanthropology (IVPP) at the Chinese Academy of Sciences in Beijing on 27 September 1977, at which time he told Huang that the third Peking Man tooth was found in 1950 (Jia and Huang 1984:19, ftnt 1). Wang and Sun (2000) labeled it 1950 following Jia and Huang.

In the early 1950s, Per Thorslund, a chaired professor of palaeontology at Uppsala University, integrated the Zhoukoudian collections into the Museum of Evolution. Zdansky (1952) mentions that Thorslund asked him to reexamine the cases containing material from China. ${ }^{2}$ Kundrát and colleagues (2015) thus argue that the third tooth must have been identified between 19 March 1951 and sometime in June 1952, when Zdansky returned to Uppsala after retiring from his position as professor at the University of Cairo, Egypt and subsequently published his article. It is still unclear if the tooth originally came from the excavation in 1921 or in 1923.

Fourth Tooth (PMU 25719, Right Upper C) - The fourth tooth was recognized on 21 March 2011 by Martin Kundrát while he and Jan Ove R. Ebbestad were examining the materials collected by Zdansky. Wu Liu confirmed that it was a right upper canine (Kundrát et al. 2015). This is the latest discovery from Zdansky's original Zhoukoudian collection, but whether it came from the 1921 or the 1923 excavation remains unclear.

\section{Summary}

In summary, due to the implicit rather than explicit nature of Zdansky's initial account of the discoveries of the first two Peking Man tooth fossils and the lack of field notes, catalogues, or labels of the specimens, the exact dates of the discovery and identification of the first two Peking Man teeth are still unclear. Whether they came from the 1921 or the 1923 excavations is also unclear. However, circumstantial evidence does suggest that the two teeth came from the deposits Zdansky excavated in 1921 and 1923 and that he identified them before May 1926. Likewise, exactly when the third tooth was identified is not clear. The only well-established date for any of the teeth is for the fourth, identified in 2011.

The timeline for the discoveries of the four Peking Man teeth currently housed in Uppsala can be formulated as follows:

1. August 1921: Zdansky excavates Zhoukoudian on assignment from Andersson; Andersson recognizes Zhoukoudian's significance as a human fossil site; first Peking Man tooth possibly unearthed and identified as Hominoid by Zdansky

2. 1923: Zdansky returns to Zhoukoudian for second excavation

3. 1924-1926: Zdansky recognizes the second tooth as Hominoid, which might have prompted him to look again at the first tooth and fully recognize their identity and significance

4. 1926: Black announces the discovery of the first two Peking Man teeth in Nature 
5. 1933: first tooth described as having been found in 1923 (Black et al. 1933)

6. 19 March 1951: Zdansky returns to Uppsala to work on the Zhoukoudian collections (reports the discovery of the third tooth in June 1952)

7. 21 March 2011: fourth tooth found by Kundrát (reported in 2015)

There is no certainty beyond these facts.

\section{DISCUSSION AND CONCLUSION}

Though no explicit conclusions can be drawn regarding the exact excavations and dates these four teeth were uncovered and recognized, it is clear that all four teeth were derived from Zdansky's 1921 and 1923 excavations, representing the earliest collection from Zhoukoudian deposits (Kundrát et al. 2015). During this phase in the infancy of palaeoanthropology, excavation practices were not yet systematic and documenting of finds was imperfect. It is therefore unsurprising that there are so many voids to be filled in the well-trodden Peking Man saga.

The obscurity surrounding the discovery of the first Peking Man fossils might furthermore reflect conflicts of personality and ambition. It has been hinted that Zdansky and Andersson's interactions were strained (Reader, 2011). If that is so, it is not surprising that neither Zdansky nor Andersson left explicit accounts of the history of these important finds. Why Zdansky did not release the news of the discovery of Peking Man fossils until 1927 remains unknown. Why did he not continue to dig at Zhoukoudian after making these finds?

These questions may never be satisfactorily answered, but Zdansky may have been influenced by personal ambition and scientific entrepreneurship. Unlike Eugène Dubois, Raymond Dart, or Davidson Black, Otto Zdansky was not interested in finding the so-called "missing link" between apes and humans (Shipman 2001; Tobias et al. 2001). He did not demonstrate the same enthusiasm towards Java man, Taung Child, and Peking Man as did other scholars of the time. He had other ambitions and scientific orientations. He mostly focused on quaternary deposits and fauna; in this regard he was successful. He may also have been disheartened by being stripped of his Ph.D. in 1940 because he was Jewish:

In times of Nazism he was deprived of his academic degree with the racist argument, that he as a Jew was not considered dignified an academic degree of a German university . . . It took 68 years since the deprivation - and a very long time since the end of Nazism - until the regranting of the doctorate took finally place in 2008 (posthumously). (Kniefacz 2014)

Black (1927) was generous in listing Zdansky as the co-founder of the new species, that is, Sinanthropus pekinensis (Black and Zdansky). That Zdansky was ambivalent about this attribution is suggested by his refraining from including his name when he reported the third tooth in the 1952 article titled, "A new tooth of Sinanthropus pekinensis Black."

In the 1910s and 1920s, the rising discipline of quaternary geology had barely begun in China. Palaeontology also represented a vast new vista, so many people became famous for working in the area there. The solid discovery of human fossils would have been particularly noteworthy in quaternary studies. Yet, as history has it, neither Andersson nor Zdansky maintained much interest in Zhoukoudian. Andersson left China somewhat reluctantly to take up new positions in Sweden, including being in charge of scientific expeditions to the Arctic and Antarctic (Fig. 3). Zdansky 
meanwhile declined an invitation to participate in further excavation at Zhoukoudian in 1927 and instead joined Cairo University as a faculty member (Reader 2011). The departure of Andersson and Zdansky from the Zhoukoudian site was a prelude to decreasing European influence on the development of the subfield of paleoanthropology as part of the fields of palaeontology and quaternary geology in China; rising American interests soon took precedence (Frängsmyr 2006, 2012; Johansson 2012; Morgan and Lucas 2002). Zdansky later declined paid employment in the influential American Expedition to Mongolia (Frängsmyr 2012).

The poor documentation resulted in uncertainty regarding the historic events surrounding the discovery of the first Peking Man fossils and has undermined Zdansky being properly credited for their identification as Peking Man fossils. For example, Schmalzer (2008:37) states merely that "in 1926 a scientist in Sweden identified two of the teeth Zdansky had collected as Homo specimens." Similarly, in Michael Day's Guide to Fossil Man (1986:367) the earliest discoveries are simply accredited in chronological order to Andersson, Zdansky, and Bohlin: "Found by: J.G. Andersson, 1921; O. Zdansky 1923; B. Bohlin, 1927.' Zdansky is not the first one listed as having found Peking Man fossils. Even earlier, in Leroy's (1971) collection of correspondence between Andersson and de Chardin, Leroy gave the year 1922 for the discoveries for first two teeth and the year 1928 for the Holotype tooth found by Bohlin; all these dates were incorrect or groundless.

Zdansky may have excavated the teeth as early as 1921, during the beginning of palaeoanthropology as a science and in the middle of a scholarly passion for finding the "missing link" in Asia. What would have happened if, at the time, he had let Andersson and the world that he had discovered human fossils in these Pleistocene deposits? Scholars already believed that East and Central Asia, including China, were the most promising regions for searching for human origins (Manias 2012). It is reasonable to imagine that Andersson and especially Black would have been overjoyed by Zdansky's discoveries and large scale excavations would have followed. More fossils might soon have been revealed, especially skulls that could be readily compared to the "Pithecanthropus erectus" found and named by Dubois in Java, which might have convinced the scientific community of its human status. That could then have changed the assumptions of emerging palaeoanthropologists. What would Raymond Dart have thought about the Taung Child in the wake of an "early establishment of Peking Man" is anyone's guess (Tobias et al. 2001:7). If Zdansky had revealed his findings at the earliest occasion, the early history of Zhoukoudian and discoveries of the first Peking Man fossils could have been documented and reported more precisely. The development of palaeoanthropology in the early twentieth century, especially in China, would have been quite different.

Such speculations aside, we know that Zdansky was the true discoverer of the very first Peking Man fossil and thus he is enshrined in the history of palaeoanthropology (Wang and Sun 2000). The four teeth remain a silent yet powerful testimony to the early stages of the human endeavor to understand our origins.

\section{ACKNOWLEDGMENTS}

This article is dedicated to Otto Zdansky, Johan G. Andersson, Davidson Black, Birger Bohlin, and other early Zhoukoudian scholars. We thank Xinzhi Wu from the Institute of Vertebrate Paleontology and Paleoanthropology (IVPP), Chinese Academy of Sciences, 
Beijing, China, for the inspiration to conduct this study. Professor Wu, currently the leading palaeoanthropologist in China, is turning 90 this year (2018). We also thank Lingxia Zhao, Lizhao Zhang, and Matthew Kesterke for their help of various kinds. The Zdansky family is appreciated for making the autobiography of Otto Zdansky available. We also thank Rowan Flad for editing this manuscript and providing constructive thoughts, along with two anonymous reviewers.

\section{NOTES}

1. "Soweit ich mich erinnern kann, lag der Molar in Schichte 5 oder 6 des Profiles A bei Zdansky (1923, S. 86). Bezüglich des Prämolaren fehlt mir eine derartige Erinnerung. Ich entdeckte ihn erst bei der Reinigung des Materiales in Upsala. Selbst wenn er von mir selbst dem Sediment entnommen worden sein sollte, ist es nur zu leicht möglich, dass er infolge des anhaftenden, feuchten Lehmes seiner Natur nach von mir nicht erkannt wurde" (Zdansky 1928:141).

2. Zdansky was still referring to the new species as Sinanthropus pekinensis Black in 1952.

\section{REFERENCES CITED}

ANDERSSON, JOHAN GUNNAR

1929 En fullständig skalle av Sinanthropus pekinensis [A complete skull of Sinanthropus pekingensis]. Svenska Dagbladet 29(12):8.

1932 Den gula jordens barn: Studier över det förhistoriska Kina [Children of the Yellow Earth: Studies in Prehistoric China]. Stockholm: Bonnier.

1934 Children of the Yellow Earth: Studies in Prehistoric China, transl. from Swedish by Ernest Classen. London: Kegan Paul, Trench, Trubner \& Co.

BLACK, DAVIDSON

1926 Tertiary man in Asia: The Chou Kou Tien discovery. Nature 118:733-734.

1927 On a lower molar hominid tooth from the Chou Kou Tien deposit. Palaeontologia Sinica, Series D 7(1):1-28.

Black, Davidson, Pierre Teilhard de Chardin, C. C. Young, and Wen Chung Pei

1933 Fossil man in China: The Choukoutien cave deposits with a synopsis of our present knowledge of the Late Cenozoic in China. Memoirs of the Geological Survey of China. Series A (11):1-168.

Boaz, N. T., AND R. L. Ciochon

2004 Dragon Bone Hill: An Ice Age Saga of Homo erectus. New York: Oxford University Press.

DAY, M. H.

1986 Guide to Fossil Man (4 ${ }^{\text {th }}$ ed.). Chicago: University of Chicago Press.

FRÄNGSMYR, TORE

2006 Pekingmänniskan: En historia utan slut [The Peking Man: A Story Without an Ending]. Stockholm: Natur och kultur.

2012 Peking Man: A new light on old discovery, in A Master of Science History: Essays in Honor of Charles Coulston Gillispie: 49-62, ed. Jed Z. Buchwald. Dordrecht: Springer.

HOWELLS, W. W.

1993 Getting Here: The Story of Human Evolution. New York: Paul \& Co. Publishing Consortium.

JiA LANPO

1999 Zhou Kou Dian Ji Shi 周口店记事 [Chronicle of Zhoukoydian] (1927-1937). Shanghai: Shanghai Scientific \& Technical Publishers (in Chinese and English).

Jia LANPO AND W. HuANG

1984 Zhou Kou Dian Fa Jue Ji 周口店发掘记 [The Story of Peking Man: From Archaeology to Mystery]. Tianjian: Kexue Jishu Press.

JohansSon, Perry

2012 Saluting the Yellow Emperor: A Case of Swedish Sinography. Sinica Leidensia 104. Leiden: Brill.

KNIEFACZ, KaTHARINA

2014 Otto Karl Josef Zdansky, in Memorial Book for the Victims of National Socialism at the University of Vienna 1938 [online repository], maintained by Universität Wien at: gedenkbuch.univie.ac.at. 
Kundrát, M., W. Liu, J.O.R. Ebbestad, P. Ahlberg, and H. Tong

2015 New tooth of Peking Man recognized in the Museum of Evolution of Uppsala University. Acta Anthropologica Sinica 34:131-136.

Leroy, Pierre

1971 Dans le sillage des sinanthropes: Lettres inédites de Pierre Teilhard de Chardin et Johan Gunnar Andersson [In the wake of sinanthropes: Unpublished letters by Pierre Teilhard de Chardin and Johan Gunnar Andersson], 1926-1934. Paris: Fayard.

Manias, Chris.

2012 The Rockefeller Foundation and the Excavation of Peking Man, unpublished report, available from The Rockefeller Archive Center (website): rockarch.org/publications/resrep/manias.pdf

Morgan, Vincent L., and Spencer G. Lucas

2002 Walter Granger, 1872-1941, Paleontologist. New Mexico Museum of Natural History and Science Bulletin 9. Albuquerque, NM: New Mexico Museum of Natural History.

Oakley, K. P., B. G. Campbell, and T. I. Molleson

1975 Catalogue of Fossil Hominids, Part III: Americas, Asia, Australasia. Publication 767. London: Trustees of the British Museum (Natural History).

READER, J.

2011 Missing Links: In Search of Human Origins. Oxford: Oxford University Press.

Sarmiento, Esteban, G. J. Sawyer, and Richard Milner

2007 The Last Human: A Guide to Twenty-two Species of Extinct Humans. New Haven: Yale University Press.

SCHMALZER, S.

2008 The People's Peking Man: Popular Science and Human Identity in Twentieth Century China. Chicago: The University of Chicago Press.

SHAPIRO, H. L.

1976 Peking Man. London: George Allen \& Unwin.

SHIPMAN, P.

2001 The Man who Found the Missing Link: The Extraordinary Life of Eugene Dubois. New York: Simon \& Schuster.

ThOr, A. C.

1984 Otto Zdansky: Mannen som gjore de första fynden av pekingmänniskan [Otto Zdansky: The man who first discovered the Peking Man], in Råttans Ar. Arsbok om Kina [The Year of the Rat: Annals of China]: 95-101, ed. A. Lennartsson. Stockholm: Svensk-kinesiska vänskapförbundet.

Tobias, P. V., Q. WANG, AND J. L. CORmack

2001 The establishment of palaeo-anthropology in South Africa and China with especial reference to the remarkably similar roles of Raymond A. Dart and Davidson Black. Transactions of the Royal Society of South Africa 56(1):1-9.

Van Oosterzee, Penny

2001 The Story of Peking Man. London: Allen \& Unwin.

WANG, QIAN, AND Li SUN

2000 Eightieth year of Peking Man: Current status of Peking Man and the Zhoukoudian site. Anthropological Review 63:19-30.

Wang, QIAN, AND P. V. Tobias

2001 An old species and a new frontier: Some taxonomic thoughts on Homo erectus. Anthropological Review 64:9-20.

WimAn, C.

1929 Die Kreide-Dinosaurier aus Shantung [Cretaceous dinosaurs of Shantung]. Palaeontologia Sinica, Series C 6(1):1-67.

WOOD, BERNARD, ED

2011 Wiley-Blackwell Encyclopedia of Human Evolution, 2 Volume Set. Chester, West Sussex: WileyBlackwell.

Wu, X., AND F. E. PoIrier

1995 Human Evolution in China: A Metric Description of the Fossils and a Review of the Sites. New York: Oxford University Press. 
Wu RUKANG 吴汝康, AND Wu XINZHI 吴新智

1996 China. Hominid Remains: An Update 7:1-105.

ZDANSKY, OTTO

1923 Üeber die Saugerknochenlager von Chou K'ou Tien [Concerning the layer with mammal bones in Chou K'ou Tien]. Bulletin Geological Society of China 5:83-89.

1927 Preliminary notice on two teeth of a hominid from a cave in Chihli (China). Bulletin Geological Society of China 5:281-284.

1928 Die Säugetiere der Quatärfauna von Chou-K'ou-Tien [Mammals of the Quaternary fauna of Chou-K'ou-Tien]. Palaeontologia Sinica, Series C 5(4):1-146.

1952 A new tooth of Sinanthropus pekinensis Black. Acta Zoologica 33:189-191.

1997 Autobiography, unpublished manuscript, 26 pp., copy held at Museum of Evolution, Uppsala University, Sweden. 